\title{
Контроль безопасности пищевой продукции Новое оборудование и методы анализа
}

\author{
Рассказывает специалист компании Shimadzu Europa \\ Стефан Mopo (Stephen Moreau)
}

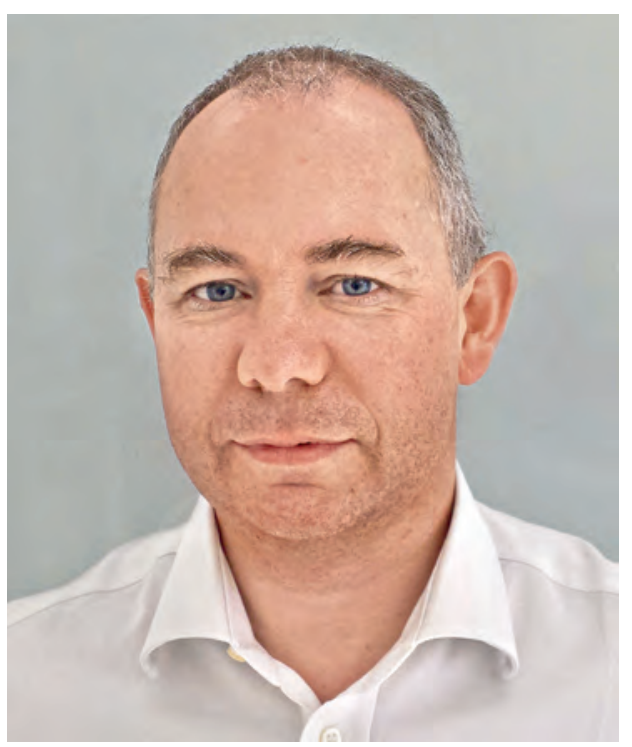

\begin{abstract}
Компания "Аналит-Продактс" и представительство компании Shimadzu в России в очередной раз собрали гостей и участников на 23-й ежегодный семинар «Аналит-Shimadzu 2019", который прошел с 15 по 18 октября в Санкт-Петербурге. По традиции на семинаре представили новинки аналитического оборудования SHIMADZU и обсудили различные аспекты использования аналитического, испытательного, общелабораторного и вспомогательного оборудования SHIMADZU и других производителей. В этом году организаторы сделали акцент на оборудовании для решения задач в области биотехнологий и медицины для научных и производственных лабораторий.

В секции "Газовая и жидкостная хроматография и хромато-масс-спектрометрия" специалист по масс-спектрометрическому и биотехнологическому оборудованию Shimadzu Europa Стефан Моро сделал доклад "Нецелевой скрининг в анализе пестицидов и контроле безопасности пищевой продукции" (DDA and DIA for food safety and pesticides screening). Г-н Моро рассказал об использовании сверхбыстрой массспектрометрии для определения остаточных количеств пестицидов в пищевых продуктах. После доклада он ответил на вопросы нашего журналиста.
\end{abstract}

Господин Моро, вы рассказали о сверхбыстрых массспектрометрах для оперативного и высокоточного анализа пищевых продуктов на содержание пестицидов. Как вы оцениваете перспективы внедрения этого метода на российском рынке?
Чтобы ответить на этот вопрос, нужно оценить не только стоимость оборудования с учетом сервиса, обучения персонала и издержек, связанных с обслуживанием, но и в первую очередь эффективность внедрения новых технологий. Когда речь идет о здоровье людей, экологические 
проблемы и способы выявления и защиты от вредных веществ выдвигаются на первый план. Компания Shimadzu начала применять сверхбыструю масс-спектрометрию для определения пестицидов в 2010 году, запустив в производство жидкостный хромато-масс-спектрометр LCMS-8030. Он заменил прежнего лидера этого сегмента - систему LCMS-2020. Сверхбыстрая масс-спектрометрия стала новым трендом на рынке масс-спектрометрического оборудования, поскольку появилась возможность получать более точные данные, больше информации за одно измерение

\section{Я с оптимизмом}

\section{оцениваю перспективы нашего оборудования на российском рынке}

и уменьшить время простоя прибора за счет увеличения пропускной способности. Сегодня я представил следующую модель жидкостного масс-спектрометра - LCMS-9030 Q-TOF, которая предназначена для выявления пестицидов в сложных пищевых матрицах. Прибор может работать в двух режимах - DDA (data dependent acquisition) и DIA (data independent acquisition). Второй режим имеет ряд преимуществ для целевого и нецелевого скрининга, поскольку прибор позволяет получать данные со скоростью до 100 спектров в секунду. Это дает возможность выявить до 197 пестицидов при целевом скрининге, а при нецелевом - проводить ретроспективный анализ образцов и идентифицировать пестициды за пределами целевого списка, облегчая возможность их обнаружения в пищевой продукции. В результате стоимость анализа одного образца уменьшается. Именно по этой причине я с оптимизмом оцениваю перспективы нашего оборудования на российском рынке. Отмечу, что область применения LCMS-9030 Q-TOF гораздо шире, чем выявление пестицидов. Например, с его помощью можно обнаруживать наркотические вещества, загрязнители, токсические субстанции и др. Капелька жидкого образца или кусочек кожи помогут получить достоверную информацию, что будет полезно криминалистам. Кроме того, LCMS-9030 Q-TOF успешно продается и работает во многих странах, а хорошие новости быстро разносятся по свету.

Как много в России дистрибьюторских центров компании Shimadzu, и как вы работаете с компанией "Аналит"одним из организаторов сегодняшнего семинара?

Компания "Аналит» - наш генеральный дистрибьютор в России, но не единственный. Наша компания представлена в разных городах и регионах России: Москве,
Владивостоке, Нижнем Новгороде, Уфе и Казани, Екатеринбурге и Новосибирске. Мы стараемся обеспечить себя хорошей логистикой в стране безграничных пространств.

Расскажите, пожалуйста, о научно-исследовательской деятельности компании.

Наша компания имеет несколько крупных научных центров, в которых работают видные современные ученые: в Японии, США, Великобритании, Китае и др. Исследователь, работающий в нашей компании, Коичи Танака, стал лауреатом Нобелевской премии в 2002 году за разработку метода ионизации MALDI для массспектрометрического анализа биологических макромолекул. Мы активно сотрудничаем с академическими учеными и инженерами. В 2016 году открыто большое производство в Малайзии, а в этом году основана научная корпорация в Kopee (Shimadzu Scientific Korea Corporation). Наши научные интересы сейчас лежат, в основном, в области биомедицины. Например, изучаем болезнь Альцгеймера: пытаемся выявить причины, совместить наши данные с результатами, полученными альтернативными способами, выявить корреляцию параметров. Исследуем источники аллергических заболеваний и способы их предотвращения с помощью нашего оборудования, которое может определять следовые количества аллергенов. В планах - оптимизация и ускорение процедуры получения результатов рутинных медицинских анализов и др.

\section{Haши научные}

\section{интересы сосредоточены на биомедицине}

\section{Что бы вы хотели сказать нашим читателям?}

Пользуйтесь оборудованием SHIMADZU, тестируйте его, сообщайте о результатах, совершайте открытия. Имея обратную связь, мы сможем сделать приборы SHIMADZU еще более качественными. И обязательно приходите на ежегодный семинар "Аналит-Shimadzu» в Санкт-Петербурге, где идет прямой разговор, и где мы демонстрируем свои последние достижения, оборудование и инновационные методики. Спасибо за поддержку нашей продукции. Мы создаем ее для вас, исследователи, ученые, кропотливые и вдумчивые химики-аналитики. Продукция нашей компании всегда рядом в ваших лабораториях и исследовательских центрах.

\section{Спасибо за интересный рассказ.}

C C. Моро беседовап А. Н. Алёшин 